\title{
Onde andarão Castana, Matilde, Sergio, Domingos, Ariosto...? Os desaparecidos como princípio formal dos romances de Chico Buarque
}

\author{
[ Whatever happened to Castana, Matilde, Sergio, Domingos, Ariosto...? \\ The missing persons as a formal principle in Chico Buarque's novels
}

\section{Juliane Vargas Welter ${ }^{\mathrm{I}}$}

RESUMO - Este artigo pretende, aliando forma literária e processo histórico-social, investigar a figura dos desaparecidos nos romances de Chico Buarque. A categoria tem se mostrado como central na feitura romanesca do autor, tendo se repetido nos romances Benjamim (I995), Leite derramado (2009) e O irmão alemão (20I4). Assim, partindo dessas narrativas, este trabalho se propõe a examinar o desparecido não apenas como marca de conteúdo, seja ele um desaparecido político ou não, mas como estruturante das obras investigadas e também como marca de uma literatura contemporânea que elabora um passado recalcado. PALAVRAS-CHAVE - Chico Buarque; romance; forma literária; desaparecidos; literatura brasileira contemporânea. · ABSTRACT .
This paper intends to investigate the role of the missing persons in Chico Buarque's novels, combining literary form and social-historical process. This category have been seen as a central mark in the author's writing, having being repeated in novels such as Benjamim (I995), Leite derramado (2009) e O irmão alemão (20I4). Therefore, taking these narratives, this paper purpose itself to examine the missing persons not only as a mark of substance, whether they are political disappearances or not, but also as a structural data from the novels and also as a mark of a contemporary literature that elaborates a repressed past. · KEYWORDS - Chico Buarque; novel; literary form; missing persons; Brazilian contemporary literature.

Recebido em I3 de março de $20 \mathrm{I7}$

Aprovado em I3 de abril de $20 \mathrm{I} 7$

WELTER, Juliane Vargas. Onde andarão Castana, Matilde, Sergio, Domingos, Ariosto...? Os desaparecidos como princípio formal dos romances de Chico Buarque. Revista do Instituto de Estudos Brasileiros, Brasil, n. 66, p. 69-85, abr. 2017.

DOI: http://dx.doi.org/IO.II606/issn.23I6-90IX.voi66p69-85

I Universidade Federal do Rio Grande do Norte (UFRN, Natal, RN, Brasil). 
Em entrevista recente, Suzana Lisboa, um dos nomes mais conhecidos no campo da militância pela busca dos desaparecidos políticos do regime militar, afirmou categoricamente: "Não há democracia onde houver desaparecidos". A sua colocação expõe a necessidade de uma reflexão sobre um problema que tem, pelo menos, duas facetas: de um lado, a não resolução de conflitos originários do nosso passado recente e as discussões suscitadas acerca de nossas políticas de memórias e de resolução de traumas, ou seja, há uma indicação para a resolução daquele passado; do outro, as possíveis consequências que essa política (ou não política) traz para o atual estágio da nossa democracia, ou seja, assinala para o presente e para um futuro. Ou, ainda, sua colocação aponta não só para o regime de exceção perpetrado pelos militares, mas também para uma democracia que mantém um estado autoritário3. Dito de outra maneira: a síntese de Lisboa nos permite discutir tanto nosso passado ditatorial quanto o nosso presente democrático instável. Ao mesmo tempo, ilumina as discussões sobre forma literária e processo histórico-social que se pretende aqui investigar.

Longe de querer realizar um debate historiográfico, o pressuposto da reflexão aqui

2 LISBOA, Suzana apud NECCHI, Vitor. Não há democracia onde houver desaparecidos. Entrevista especial com Suzana Lisboa. Instituto Humanitas Unisinos, $\mathrm{I}^{\circ}$ de março de 20I7. Disponível em: 〈http://www.ihu.unisinos. br/565160-nao-ha-democracia-onde-houver-desaparecidos-entrevista-especial-com-suzana-lisboa >. Acesso em: 3 mar. 2017 .

3 Emblemático caso do nosso estado autoritário foi o desaparecimento de Amarildo, pedreiro morto por policiais militares no Rio de Janeiro, símbolo do genocídio da comunidade negra e pobre no Brasil. Ao mesmo tempo, o crime ser cometido por policiais militares assinala já uma das heranças macabras do regime militar. Para outros detalhes, ver: BRUM, Eliane. Onde está Amarildo?. Época, 5 de agosto de 2013 (atualizado em I5 de agosto de 2013). Disponível em: <http://epoca.globo.com/colunas-e-blogs/eliane-brum/noticia/20I3/o8/ onde-esta-bamarildob.html $>$. Acesso em: 7 mar. 2017. 
proposta é: a ditadura civil-militar ${ }^{4}$ corresponde a um passado recente e traumático recalcado na sociedade brasileira. A afirmação é corroborada por políticas de Estado, como a Lei da Anistia5, de I979, que concedeu perdão a todos os que cometeram "crimes políticos ou conexos a eles", lei emblemática das políticas de memória do Estado brasileiro. Paul Ricoeur ${ }^{6}$ já chamou a atenção para as semelhanças mais do que semânticas entre os vocábulos anistia e amnésia: propondo um perdão simulado, leis desse tipo funcionariam mais como uma prática de esquecimento institucionalizado do que como uma resolução de conflitos. Desse modo, anistia e esquecimento balizariam, pelo nosso pressuposto, a nossa relação com o violento regime militar, que teve um desfecho conciliatório endossado por políticas como a lei supracitada.

Tratando-se então de um trabalho que tem como foco a produção literária, a primeira questão que se levanta é qual o impacto dessas políticas no campo literário hoje, já que o estudo aqui proposto se circunscreve em um debate sobre a literatura contemporânea em período democrático. De maneira mais genérica, a profusão de narrativas recentes sobre esse passado já é um começo de resposta7. Contudo, estando interessado nas relações entre literatura e sociedade, este artigo almeja investigar não os enredos que transitam por esse tema, mas as formas que se estruturam a partir dessa (e nessa) discussão.

Isto posto, o foco desta investigação é relacionar forma e processo histórico-social tendo em vista um dispositivo narrativo que tem se mostrado frequente nos romances de Chico Buarque, os desaparecidos, políticos ou não. Assim o objetivo é examinar esses desaparecidos como estrutura das narrativas e também como marca de uma literatura contemporânea. Arrisco dizer que o romancista criou sua própria

4 Convencionou-se datar esse regime entre os anos de I964-I985. Contudo, os debates mais recentes apontam que a data mais acertada seria I988, momento em que há uma nova constituição e podemos então falar em democracia (ou redemocratização). Para outros detalhes, ver: CAMPOS, Pedro Henrique Pedreira. Estranhas catedrais: as empreiteiras brasileiras e a ditadura civil-militar. Niterói: Eduff, 20I4. Assunto ainda em disputa, compartilhamos da datação de I988 no presente trabalho, tendo como horizonte a Constituição Cidadã. No campo literário, uma das primeiras obras, salvo engano, a tratar do tema dos desaparecidos políticos tendo como dispositivo o viés memorialístico é o romance de Caio Fernando Abreu Onde andará Dulce Veiga? (I990). Assim, o tratamento do regime com a marca da rememoração só se dá após a Constituição, momento em que a ditadura parece se erguer de fato como um marco do passado. Para outros detalhes, ver: ABREU, Caio F. Onde andará Dulce Veiga? Um romance b. Rio de Janeiro: Agir, 2007.

5 BRASIL. Presidência da República. Casa Civil. Subchefia para Assuntos Jurídicos. Lei n. 6.683, de 28 de agosto de I979. Concede anistia e dá outras providências. Disponível em: <http://www.planalto.gov.br/ccivil_03/leis/ L6683.htm>. Acesso em: 3 mar. 2017.

6 RICOEUR, Paul. A memória, a história, o esquecimento. Campinas: Editora da Unicamp, 2007.

7 Para nos limitar somente aos recentemente lançados, sem intenção de esgotar a lista: K. Relato de uma busca e Os visitantes (Bernardo Kucinski, 20II e 20I6); Cabo de guerra (Ivone Benedetti, 20I6); A resistência (Julián Fuks, 20I5), Volto semana que vem (Maria Pilla, 20I5). Importante frisar que as duas últimas obras versam também sobre o regime argentino. Para outros detalhes, ver: WELTER, Juliane V. E se estou vendo fantasmas?. Resenha de Cabo de guerra, de Ivone Benedetti. Blog da Boitempo, 29 de julho de 20I6. Disponível em: <https:// blogdaboitempo.com.br/20I6/07/29/e-se-estou-vendo-fantasmas $>$. Acesso em: 3 mar. 2017. 
fórmula romanesca: desaparecido, ideia fixa e busca e, pela leitura que propomos, essa é a formalização de um passado recalcado que é interno e externo às obras. Assim, nos três romances que serão analisados, Benjamim (I995), Leite derramado (2009) e O irmão alemão (2013), há desaparecidos que se convertem em ideias fixas dos protagonistas/narradores. Isto é, são eles os vetores da narrativa, os responsáveis pela rememoração, pela busca de um passado e pelas problematizações de um futuro, explicitando o princípio compositivo das obras ${ }^{8}$. Da mesma maneira, há personagens desaparecidos, a princípio lateralizados, que acabam por reforçar essa composição.

Importante frisar que essas narrativas não são centralizadas no regime militar, podendo inclusive ser lidas sem essa chave interpretativa, sobretudo Leite derramado. Porém, sendo uma marca que estrutura os romances, pela nossa hipótese, ao mesmo tempo que retoma uma categoria tão peculiar ao Estado brasileiro, entendemos que, ao se valer dos desaparecidos como princípio formal, Chico Buarque está reatualizando passados que se referem à nossa matéria externa, permitindo, assim, que se ilumine a discussão estética e se amplie o debate sobre a atual literatura brasileira e suas relações com a sociedade.

\section{“DEUS TE LIVRE, LEITOR, DE UMA IDEIA FIXA"9}

Logo após o lançamento de Estorvo (I99I), primeiro romance de Chico Buarque, Roberto Schwarz escreveu a resenha "Um romance de Chico Buarque", na qual não economiza elogios: "Estorvo é um livro brilhante" enredo trata da saga de um personagem não nomeado, vivendo entre a alucinação e a realidade, em fuga - não sabemos do quê - em uma cidade e um tempo nada cordiais. O seu périplo em espiral vai desde a fazenda da família (dado de classe não gratuito que aponta já para uma contemporaneidade decadente) agora transformada em uma plantação de maconha (e na qual residem supostos bandidos) até o protagonista ser esfaqueado por um estranho (ao confundi-lo com um amigo e abraçá-lo). Laterais,

8 A presente investigação é a ampliação e o desdobramento de um debate proposto na tese Em busca do passado esquecido: uma análise dos romances Onde andará Dulce Veiga? (I990), de Caio Fernando Abreu, e Benjamim (I995), de Chico Buarque, defendida na Universidade Federal do Rio Grande do Sul em abril de 20I5, sob orientação do prof. dr. Homero Vizeu Araújo. Naquele momento, tendo como foco somente o romance Benjamim entre as obras de Chico Buarque, a problematização dos desaparecidos não era central, já que o interesse era o exame da figura da testemunha à brasileira (nomenclatura que depois pode ser revista/ ampliada para delator à brasileira, já na esteira das discussões políticas posteriores à escrita da tese). WELTER, Juliane Vargas. Em busca do passado esquecido: uma análise dos romances Onde andará Dulce Veiga? (I990), de Caio Fernando Abreu, e Benjamim (I995), de Chico Buarque. 20I5. 267 f. Tese (Doutorado em Estudos Literários). Programa de Pós-Graduação em Letras, Instituto de Letras, Universidade Federal do Rio Grande do Sul, 2015. Disponível em: 〈http://www.lume.ufrgs.br/handle/IOI83/II7544>. Acesso em: 4 mar. 2015.

9 ASSIS, Machado de. Memórias póstumas de Brás Cubas. São Paulo: Klick Editora, I997, p. 2I.

Io SCHWARZ, Roberto. Um romance de Chico Buarque. In: Sequências brasileiras. São Paulo: Companhia das Letras, I999, p. I78. 
mas não menos importantes, personagens secundários marcados pelo fetiche da própria imagem.

Na acepção do crítico, a lógica formal está dada em uma linguagem despretensiosa que engendra a diluição das fronteiras entre as categorias sociais e o mundo da imagem. Diz Schwarz: "Estaríamos forçando a nota ao imaginar que a suspensão do juízo moral, a quase-atonia com que o narrador vai circulando entre as situações e as classes seja a perplexidade de um veterano de I968?" II. Se aceitamos essa premissa, o narrador em fuga se choca com o mundo a sua volta exatamente por não o compreender. Assim, essa disposição em "continuar igual em circunstâncias impossíveis" seria "a forte metáfora inventada para o Brasil contemporâneo, cujo livro [Chico Buarque] talvez tenha escrito” ${ }^{2}$. Aceitando ou não a ideia de que o narrador de Estorvo é um personagem de I968, o que temos em Benjamim é a realização dos comentários críticos de Schwarz na figura do protagonista atormentado pelo seu passado e não menos atônito. Porém, essa não compreensão é agora mediada pela terceira pessoa e não fica menor, pois o artifício narrativo aponta para um personagem que não teria condições de narrar a própria história.

Benjamim, protagonista homônimo do romance, configura-se como um personagem patético, beirando alguma ingenuidade, o que não permite propriamente empatia com ele, apesar de certa indulgência do narrador. Soma-se a isso o deslocamento do personagem no seu tempo, provavelmente final dos anos I980, início dos I990; e, também no seu espaço, um provável Rio de Janeiro em meio a novas configurações sociais e à violência, como o pastor evangélico candidato a deputado ou, ainda, o mundo da imagem e da propaganda, que já havia sido explorado pelo romancista na sua obra anterior. O enredo é bastante simples: homem de 50 anos encontra uma jovem moça, muito parecida com uma ex-namorada da juventude, e fica obcecado por ela. A jovem, Ariela Masé, seria supostamente (pela perspectiva de Benjamim e não negada pela voz que narra) filha de Castana Beatriz, namorada do personagem nos anos I960 que foi fuzilada pelos militares durante a ditadura. Assim, ao reconhecer na jovem semelhanças com a ex-namorada, Benjamim supõe ser ela a filha de Castana. Tendo em vista que o personagem é abandonado pela namorada, há uma tentativa de reconciliação projetada agora em Ariela.

A singularidade se dá porque esse encontro dispara rememorações acerca daquele passado e da responsabilidade de Benjamim na morte dessa namorada, informações que estavam até então esquecidas para o personagem. Assim, através da voz narrativa em terceira pessoa, acompanhamos um processo de reconstrução do passado apagado até o encontro com Ariela, que acabará por revelar o papel do nosso protagonista no assassinato de Castana: espécie de delação (entre o voluntarismo e o involuntarismo) que permitirá que os militares encontrem seu esconderijo. A jovem funciona assim como um gatilho que permite que a memória represada venha à tona juntamente com uma possível culpa.

Esse exercício de reelaboração do vivido em meio às atenções da jovem levará o

II Ibidem, p. I80.

I2 Ibidem, p. I8I. 
personagem a pensar (uma única vez) em declarar: "Eu matei a tua mãe”3. Ou seja, o dado de admissão de responsabilidade é uma suposição e não uma afirmação. Assim, esse encontro fantasiado de reencontro transformará Ariela em uma ideia fixa, o seu emplasto, para usarmos os termos de Brás Cubas, que o conduzirá à morte. Não é forçado dizer que essa fixação por si só aponta para a culpa pensada pelo próprio Benjamim, mas nunca admitida nem por ele nem pela voz narrativa, índice corroborado pela memória recalcada que anos depois retorna. Buscando em Ariela a ex-namorada Castana e consequentemente a reconciliação com os atos passados, acompanhamos o fracasso dessa tentativa conciliadora, já que impedida pelo dado do enredo, a morte (provocada pela própria ideia fixa), e pelo dado da forma, o eterno retorno à cena inicial, a morte.

Quanto ao narrador, ele assume o discurso indireto livre e funciona como uma câmera, pela força da imagem, mediando toda a narrativa, o que inclui a memória dos personagens centrais (Benjamim, Ariela e Alyandro, o pastor candidato a deputado). O seu comportamento pode ser visto ou como um comportamento autoritário - temos poucos discursos diretos ao longo de todo o romance -, ou como uma solução para personagens incapazes de narrar a si mesmos. Assim, o passado é visto como culposo por Benjamim, muito mais pelas pistas deixadas por ele e pelo narrador do que por uma admissão de responsabilidades, dado que é suavizado pelas posturas daquele que narra e faz reflexões sobre o rememorar:

É possível que os momentos que acabamos de viver subitamente se apaguem na nossa consciência, e se transformem em medo, desejo, ansiedade, premonição. E naquilo que temos por reminiscência talvez esteja um destino que, com jeito, poderemos arbitrar, contornar, recusar, ou desfrutar com intensidade dobrada ${ }^{\mathrm{T} 4}$.

Dessa forma, a estrutura funciona como um artifício na construção da falta de responsabilidade de Benjamim e aponta para uma instabilidade do romance: a narrativa memorialística em terceira pessoa de um narrador cego às ações do protagonista e que assume a sua perspectiva. Estruturado como a posição de uma câmera em um movimento circular, quase espiralado, como em Estorvo, o romance vai freneticamente de um personagem ao outro, de um espaço ao outro e de um tempo ao outro, mas com Benjamim ocupando posição central. Se o narrador em terceira pessoa pode vir a ser um narrador distanciado, aqui ele perde esse afastamento: 0 indireto livre confunde as vozes e o leitor com um dispositivo que permite que ele vá do personagem para o narrador e desse para o personagem. Ao mesmo tempo, ao se travestir de câmera, poderíamos inclusive pensá-lo em um narrador que emularia uma posição observadora, mas isso é falso. Assim, a problemática da terceira pessoa como narradora das memórias, traumas e mortes no romance é aquela que, além de dar voz ao aparvalhado protagonista, medeia as reminiscências e culpas sentidas por ele.

Concomitantemente, a ciclicidade formal, índice estético já apontado por Walter

I3 BUARQUE, Chico. Benjamim. São Paulo: Companhia das Letras, 2004, p. 98.

I4 Ibidem, p. 53-54. 
Garcia $^{\text {15 }}$ na canção buarquiana - e que pode ser replicado para os romances Estorvo, Benjamim e Leite derramado -, constrói o tempo circular praticamente didático: as primeiras e últimas orações são idênticas, dado formal e de enredo, com Benjamim em frente ao pelotão de fuzilamento, do que se depreende a sua morte. Se não há um defunto-autor, há um narrador, colado ao protagonista, que elabora a linguagem à beira da morte. Isto é, a linguagem é concebida a partir dessa perspectiva, ação possível graças à ideia fixa Ariela e às reminiscências que ela traz ${ }^{\mathrm{I}}$.

A forma utilizada permite assim que o fracasso reconciliatório de Benjamim também atinja o leitor, preso em um eterno retorno com o final do romance remetendo para o seu início e assim sucessivamente. Para Benjamim, essa ciclicidade aponta para a falta de saída e não para a resolução, estando ele destinado àquele fim, pela perspectiva empática do narrador, que lhe usurpa as responsabilidades. Ou seja, a desaparecida Castana Beatriz, represada na sua memória pelo trauma da delação, é trazida à tona pelo encontro com a jovem Ariela e não há resolução possível para um passado irreversível. Dito de outra maneira: o passado violento recalcado vem assombrar como fantasmagoria o presente não menos violento do personagem. A solução de enredo, a morte. A solução da forma, o ciclo repetitivo e sem saída que só pode levá-lo à morte. Sem resolução do passado, sem apontamentos para o futuro.

Já Leite derramado traz o narrador-personagem Eulálio, um senhor centenário que, no leito de um hospital, perpassa a história de sua família senhorial e, por consequência, atravessa a própria história brasileira ao mesmo tempo que relembra Matilde, a esposa desaparecida. Valendo-se assim da memória, a qual considera "uma vasta ferida"ㄱ, o personagem retoma o passado glorioso de seu círculo familiar, posição que lhe conferiu uma série de privilégios ao longo da vida, mas sempre costurando essas reminiscências com a rememoração de sua ideia fixa, Matilde. Mistura de Brás Cubas, com sua desfaçatez de classe, só que agora centenário e beirando o ridículo, e Bento Santiago, com seu ciúme imaginativo, referência quase explícita na narrativa, acompanhamos os disparates de um protagonista deslocado no seu tempo, como nosso protagonista anterior, e preso a uma cama de hospital, o que já pressupõe o seu estar à beira da morte, repetindo o drama anterior.

Assim, nesse jogo não linear da memória, temos acesso a uma versão do século XX brasileiro vista pelos de cima. Ou melhor, acompanhamos a violência estrutural de uma sociedade pautada pela cordialidade, pelo compadrio e pelo direito de posse, dado que alcança tanto o passado escravocrata quanto a relação com os libertos e com a esposa. Esses índices são medidos tanto pelas representações da família de fidalgos

I5 GARCIA, Walter. De “A preta do acarajé” (Dorival Caymmi) a "Carioca” (Chico Buarque): canção popular e modernização capitalista no Brasil. Música Popular em Revista, Campinas, ano I, v. I, p. 30-57, jul.-dez. 2012. Disponível em: 〈http://www.publionline.iar.unicamp.br/index.php/muspop/article/view/28/46>. Acesso em: 8 abr. 2017.

I6 Essa articulação entre ponto de vista da morte e ideia fixa, que será retomada adiante, se orienta a partir da investigação de José Antônio Pasta Jr., que entende esse dado como um recorrente estrutural na literatura brasileira. Para outros detalhes, ver: PASTA JÚNIOR, José Antonio. O ponto de vista da morte. Revista da Cinemateca Brasileira, v. I, p. 7-I5, 2013.

I7 BUARQUE, Chico. Leite derramado. São Paulo: Companhia das Letras, 2009, p. Io. 
quanto pelas falas do narrador, em primeira pessoa, que deixa desvelar essas tensões. Contudo, em pleno século XXI, o que observamos é o declínio dos Assumpção, "pai rico, filho nobre, neto pobre" ${ }^{\text {"18 }}$, e a inadequação do personagem aos novos tempos, estando completamente "fora do lugar" em 2007 - ele nasce em I907. Essa condição, que é do narrador e não do leitor, atua como o dispositivo que transforma as falas racistas, sexistas e classistas do antigo senhor de escravos em piada, o que dá o humor do livro sem perder a articulação com a violência dessas percepções.

Eulálio conta suas histórias a partir do leito do hospital, acamado e sem mobilidade. Apesar disso, a sua movimentação se dá espacial e temporalmente, com vaivéns narrativos que atravessam a história oficial do Brasil e uma sociedade em modificação já no século XX. A marcação discursiva aponta para uma enfermeira que estaria escrevendo essas memórias, mas não há nenhum dado material que comprove que isso de fato aconteceu, a impressão é exatamente contrária: em certos momentos fica bastante claro que a sua conversa se dá com o teto. Além do que, ao misturar planos e tempos, não sabemos o quanto há de real ou invenção na fala desse narrador. Assim, não é errado dizer que o romance se constrói como um monólogo sobre Matilde, intercalado com a história da família ou, ainda, do Brasil. Ponto alto da formalização se dá pela autoconsciência do narrador, que afirma: "lembrança de velho não é confiável”’’; ou, ainda, "porque cada lembrança já é um arremedo de lembrança anterior" ${ }^{20}$, sempre marcando que o seu rememorar é de um passado longínquo, centro de sua história: “'́á para o passado tenho um salão cada vez mais espaçoso” "ז. Porém, a autoconsciência é marcada por uma série de delírios, o que faz com que desconfiemos dessa voz o tempo inteiro.

Ideia fixa do narrador, que não sabe o seu destino, Matilde é marcada por seu comportamento simples, sua espontaneidade e suas relações com os empregados, dados que levam muitas vezes Eulálio a se sentir desconfortável do alto de sua condição de classe. Ao mesmo tempo, tem uma "pele quase castanha" ${ }^{22}$, não sendo culta e sofisticada como a família Assumpção esperava. Todavia, a relação é assinalada desde o começo como uma obsessão: "Olhando meu corpo, tive a sensação de possuir um desejo potencial equivalente ao dele [o pai], por todas as fêmeas do mundo, porém concentrado numa só mulher"23. Casam-se, têm uma filha e tempos depois Matilde desaparece, permanecendo seu destino incógnito: teria fugido com um amante? Teria ido para um hospício? Teria contraído alguma doença grave? Perguntas que ficam sem respostas ao longo do romance, com a marcação de versões sobre o que poderia ter acontecido na "trágica desaparição de Matilde” ${ }^{4}$. Importante

I8 Ibidem, p. 38.

I9 Ibidem.

20 Ibidem, p. I36.

2 I Ibidem, p. I4.

22 Ibidem, p. 20.

23 Ibidem, p. 33.

24 Ibidem, p. I88. 
frisar que o desaparecimento se dá aos olhos do narrador, visto que é possível falar em uma fuga da personagem daquele ambiente que pode ser visto como opressor.

Seu desaparecimento repentino, relembrado agora no leito do hospital, é marcado pela busca do personagem nos meandros da memória e da própria casa, "depois que ela saiu da minha vida, mantive o capricho de procurá-la do mesmo jeito, toda noite”25, e pela reconstrução do ciúme de Eulálio, ao melhor estilo Bento Santiago: imaginativo e construído em primeira pessoa. Ao desaparecimento de Matilde se sobrepõe um desaparecimento lateralizado, o de seu neto, jovem comunista que se envolve na luta contra a ditadura militar e tem um filho com uma jovem militante negra, o que permite os explícitos desvarios racistas da família Assumpção.

Assim como Benjamim, não há encontro com o desaparecido do passado, com um desfecho que é marcado pela morte do protagonista sobreposta agora à morte do avô, como um ciclo. Sem esquecer, é claro, que nesse caso não estamos falando de desaparecidos políticos, e sim de uma desaparecida que é a obsessão do narrador e que permeia a sua rememoração. Em síntese: se não há reflexões sobre o passado traumático do regime, ficando o jovem Eulálio Neto lateral na construção, há reflexões sobre um estado autoritário e senhorial; se o desaparecido político é secundário, há uma desaparecida que dispara a narrativa e que faz assim se desvelar uma violência que ultrapassa os limites de um regime ditatorial que estrutura a sociedade.

Ao mesmo tempo, novamente estamos em frente a um personagem deslocado no seu tempo: se Benjamim tem uma vida solitária e desapegada daquele mundo contemporâneo, vivendo dos trabalhos da juventude e fazendo propagandas de mau gosto, situado assim em uma classe média com algum conforto, Eulálio, representante dos de cima que decaíram, só pode viver de favores. Contudo, ambos se encontram na inadequação do mundo a sua volta, que não é aquele ao qual estavam confortáveis e sim um mundo marcado pela decomposição das relações antes conhecidas, tão violento quanto aquele passado. Esse não é propriamente um dado negativo, visto que as relações anteriores dessas personagens eram marcadas também por violências de classe, gênero e raça, essa última ficando evidenciada sobretudo com os Assumpção.

Além disso, ambos constroem suas histórias através da memória, ou seja, uma criação calcada na realidade, mas ainda um trabalho criativo e individual que se manifesta após negociações e conflitos. Se em Eulálio essa condição é explicitada com um narrador que de antemão admite que a sua memória "de velho" pode vir a falhar, com Benjamim ela é mais enganadora, já que se quer afastada. Da mesma maneira, as escolhas que a memória faz e que o discurso engendra mostram como essa história os constitui como sujeitos: esse olhar para o passado marca a própria ausência de futuro, dado de enredo e de forma. Concomitantemente, Castana e Matilde são aquelas que faltam e são buscadas não na presença material, mas replicadas na jovem Ariela ou na memória. Ambos fracassam e só encontram a morte.

Já O irmão alemão, obra atravessada pela vida privada do autor ${ }^{26}$, isto é, embasado

25 Ibidem, p. 46.

26 Para outros detalhes, ver: SILVA, Fernando Barros e. O irmão brasileiro. Piauí. Edição Ioo, janeiro de 2015.

Disponível em: 〈http://piaui.folha.uol.com.br/materia/o-irmao-brasileiro >. Acesso em: 4 mar. 2017. 
em um drama familiar real mas entrecortado pela criação ficcional, centra-se, sumariamente, na busca de Francisco de Hollander pelo meio-irmão alemão, a sua ideia fixa, fruto de um relacionamento do pai durante sua estadia em Berlim. $\mathrm{O}$ argumento é armado pela "busca de filiação" ${ }^{27}$ do pai pelo narrador, que se sente preterido em relação ao irmão mais velho, Domingos. Enquanto procura o meio-irmão Sergio, que pode ter sido morto na Alemanha nazista, concomitantemente, no Brasil, esse mesmo Francisco, em história a princípio lateral, perde o irmão brasileiro, desaparecido político na ditadura brasileira. Está dado, dessa forma, o curto-circuito formal. Se Francisco nunca morreu "de amores por aquele irmão" e "o teria trocado por um irmão alemão sem pestanejar”, passou agora a se "inquietar com a ameaça de ficar sem irmão nenhum" ${ }^{28}$. Dito de outra maneira, se a trama se constrói como a busca do irmão alemão, o desparecimento do irmão brasileiro revela um novo centro.

Ademais, soma-se a Domingos outro desaparecido político, Ariosto, amigo de infância do protagonista. Se o envolvimento do irmão não é explícito, o seu sumiço parece mais um fruto do acaso ao acompanhar - por motivos sexuais, segundo o narrador - uma jovem montonera em São Paulo. Ariosto já havia sido preso e, talvez, torturado (segundo a imaginação do narrador). A retomada dos desaparecidos ou, ainda, a retomada, dentro do seu próprio universo romanesco, de figuras não heroicas como Benjamim e Francisco (e até mesmo Eulálio), aponta para uma marca autoral bem presente na obra de Chico romancista: esse olhar para uma média, sem idealizações, já que a perspectiva narrativa se dá a partir daqueles que não participam das movimentações políticas. Dado que não impede que percorramos parte do século XX ocidental, com regime nazista na Europa e militar no Brasil, demonstrando o fôlego do romancista na busca de sínteses do seu tempo, arrisco dizer.

Narrado em primeira pessoa, com um narrador e um ambiente altamente intelectualizados - até "então, para mim, paredes eram feitas de livros"29, revela Francisco-, de uma classe confortável, mas sem luxos, o gatilho é uma carta de Anne, mãe do meio-irmão, encontrada em um livro do pai. Em meio a situações altamente imaginativas, já que o narrador sempre antecipa prováveis acontecimentos e desdobramentos - antes mesmo de entender a carta, escrita em alemão, já fantasia sobre a possibilidade de um irmão alemão -, e pela violência naturalizada de uma família patriarcal de classe média (com machismo e sexismo muito marcados), somos conduzidos por esse narrador obcecado pelo meio-irmão, projeção do pai e do conflito com o irmão brasileiro. Ao mesmo tempo, a antipatia do narrador para com o irmão daqui acaba por conduzir a narrativa de maneira que o leitor também não simpatize com ele. Contudo, a empatia com o narrador também não é possível, visto que ele se revela também nas relações machistas e sexistas, sendo um personagem mesquinho que carrega em si como índice positivo apenas o mundo letrado e da cultura.

Entretanto, o desaparecimento de Domingos acaba por mudar o ritmo da narrativa funcionando como um gatilho para o desfecho, barrando parte das imaginativas suposições de Francisco na forma e no enredo. Isso se dá pois há uma derrocada

27 BUARQUE, Chico. O irmão alemão. São Paulo: Companhia das Letras, 2014, p. 53.

28 Ibidem, p. I60.

29 Ibidem, p. I6. 
da família: o pai falece logo em seguida, e a mãe morre de "saudades do Mimmo"30. Assim, tendo Sergio Ernst como motivo, a sua ideia fixa, o romance se arma pelo desaparecimento e pela busca, que projetam uma relação familiar tortuosa com pai e irmão brasileiro, explicitando por fim a centralidade não do irmão alemão, mas do irmão brasileiro, ponto instável do romance. Nenhum deles (re)aparece: se o primeiro conseguiu não ser levado pelo Estado nazista, falecendo já em idade avançada, o segundo não teve a mesma sorte, entrando para a lista de desaparecidos políticos.

Importante apontar que, além dos desaparecidos, chave reatualizada nesse romance, outra repetição é a morte que assombra: em Benjamim, Castana é morta pelo regime militar, e Benjamim morre no agora narrativo; em Leite derramado, Matilde desaparece, espécie de morte simbólica, e Eulálio morre no presente, junto com a narrativa - sem esquecer do neto Eulálio, também morto pelo regime militar, como Castana; agora acompanhamos o desaparecido Sergio, que só é encontrado depois de sua morte; Domingos é mais uma vítima da ditadura (assim como Ariosto, o amigo de infância); e, por fim, Francisco, que, se não morre no agora narrativo, aponta para um fim simbólico, já que só encontra o irmão em 20I3, já falecido, finalizando assim uma busca incompleta.

Esse estar à beira da morte é aqui entendido a partir das investigações de José Antônio Pasta Jr. sob o ponto de vista da morte como um recorrente estrutural na literatura brasileira. Segundo a sua categorização, ao mergulhar nos impasses estruturais da sociedade brasileira, só um regime de limite, um ponto de vista impossível, seria capaz de dar conta internamente desses problemas, reflexão que se dá a partir, especialmente, de Brás Cubas, sujeito formado entre o escravismo brasileiro e o liberalismo europeu. Ou seja, sujeito dual, formado por contradições, a ideia fixa seria a própria busca de uma completude em meio à formação ambivalente do Estado-nação brasileiro ${ }^{31}$.

No romance machadiano, a ideia fixa, o emplasto, e a "sede de nomeada" o levam à morte. Agora, nos romances buarquianos as ideias fixas, isto é, os desaparecidos, não dizem respeito a vaidades de protagonistas e narradores, mas a passados mal resolvidos, que, se não levam os personagens à morte diretamente - com exceção de Castana-Ariela -, dão o tom de uma incompletude que paira no conteúdo e na forma, em um processo de introjeção de um dado que é externo. Ou melhor, resgatando as afirmações de Schwarz: se o personagem de Estorvo pode ser lido como um personagem de I968 ou, ainda, se o romance pode ser lido como uma metáfora do Brasil, com sua disposição de continuar igual em circunstâncias improváveis ${ }^{32}$, o que resta para Benjamim (e seu narrador), Eulálio e Francisco?

Esperamos ter deixado claro até aqui o que consideramos o princípio compositivo dos romances de Chico Buarque reforçado ao longo desses três romances. Em síntese: desaparecido - ideia fixa - busca. Por comparação e contraste é possível iluminar essa estruturação que parece se ensaiar já desde o primeiro romance de Chico Buarque, como sugere o texto de Roberto Schwarz.

30 Ibidem, p. I89.

3I PASTA JÚNIOR, José Antonio, op. cit.

32 SCHWARZ, R. Um romance de Chico Buarque, op. cit., p. I80-I8I. 
O dado central: os desaparecidos que se transformam em ideias fixas. A lembrança do emplasto machadiano não é gratuita, é claro. Sem forçar a nota, pode-se dizer que a busca desses sujeitos (Benjamim, Eulálio e Francisco) se dá em meio a não resoluções do passado, que são individuais, mas carregam em si um índice de coletividade, seja pelo assassinato de Castana em meio ao regime militar, pelo desaparecimento de Matilde no seio da família senhorial e pelo desaparecimento lateral de Eulálio Neto, também em consequência do regime, seja, ainda, pelo desaparecimento de Domingos também durante o regime militar (e de Ariosto) e pelo de Sergio, que, se não desaparece pela violência do Estado (aqui ou lá), é sujeito a um violência simbólica e material de abandono parental.

Concomitantemente, falamos de narradores que assumem, pelo menos em Benjamim e Leite derramado, o ponto de vista da morte: Benjamim e seu narrador (que se faz no discurso a partir desse momento) começam o romance em frente ao pelotão de fuzilamento, e Eulálio está acamado. Se Francisco, o único que não faz uso exclusivo da memória no seu discurso, não está à beira da morte, todos os personagens de sua vida vêm a falecer, tendo ele mesmo uma morte simbólica ou, pelo menos, um fim de narrativa, ao encontrar notícias do irmão alemão somente após o seu falecimento. Se através dos desaparecidos há uma tentativa de recompor um passado ou solucionar conflitos, o estar sob a perspectiva do fim já aponta para a impossibilidade dessas soluções. Dito de outra maneira, as buscas são a própria tentativa de recompor o passado e resolver o presente e, quem sabe, o futuro: Benjamim delata a ex-namorada, busca em Ariela o passado; Eulálio perde Matilde, e busca na memória respostas para seu desaparecimento; Francisco tenta resolver uma relação com o pai na procura pelo irmão perdido, mas perde o outro irmão. As suas ideias fixas, as suas procuras por esses personagens, formalizam uma tentativa de resolução, com a busca introjetada na estrutura em uma tentativa de narrativa total daquelas vidas em seus cíclicos tempos. Para tanto, é na memória, nessa invenção de um passado, que os textos se erguem. Se em Benjamim e Leite derramado ela é central, em $O$ irmão alemão é a partir do desaparecimento de Domingos que o ritmo ganha em agilidade e, por fim, em rememoração, funcionando assim esse dispositivo como fundamental na elaboração dos personagens desaparecidos, já que no presente eles nunca serão encontrados.

$\mathrm{O}$ dado aterrador se dá porque nenhum deles consegue resolver seus conflitos. $\mathrm{Ou}$, ainda: aquele passado não é passível de solução, já que marcado por violências que atravessam aqueles sujeitos e os constituem. Por fim, nos deparamos então com dois protagonistas literalmente mortos ao fim da narrativa, sem falar nos desaparecidos, que também têm o dado da morte. Ou seja, não há conciliação possível, nem no enredo, nem na forma: a circularidade e a ciclicidade das narrativas impedem que uma outra história seja contada.

Retomando o argumento de Walter Garcia sobre a canção, agora transposto aos romances ${ }^{33}$, a experiência do tempo cíclico em Chico Buarque se mostrou, em Estorvo, espiral e rebaixada rumo à degradação final do narrador. Em Benjamim ${ }^{34}$ (I995) e Leite

33 GARCIA, Walter, op. cit., p.49.

34 BUARQUE, Chico. Benjamin, op. cit. 
derramado ${ }^{35}$ ela é quase didática. No primeiro, a oração inicial repete-se na oração final: saímos e voltamos para a mesma cena. No segundo, a morte do narrador sobrepõe-se à morte do avô, como uma única morte, e o fim de um ciclo. A repetição estava (ex)(im)plícita em "Carioca”, canção analisada no referido artigo ${ }^{36}$, o que se dá em Benjamim e Leite derramado, mas agora esse repetir se ergue como um eterno retorno sem fim e sem possibilidades de mudança, afinal, não há possibilidades de modificações para a morte.

As disparidades se dão na voz narrativa, com um Benjamim apatetado, sem condições de narrar a sua própria existência, sendo narrado então por uma voz em terceira pessoa acoplada ao protagonista como uma câmera. O que problematiza a própria estratégia da memória como marca formal. Já Eulálio, do alto de sua condição de classe, fala por si mesmo e ainda imagina estar citando o seu próprio livro de memórias para alguém que o redige; Francisco, o mais intelectualizado de todos, uma primeira pessoa tão imaginativa para falar do irmão alemão e de possíveis desdobramentos dessa história quanto era Eulálio para imaginar cenas de adultério de Matilde. Falamos assim de narradores diferentes que, todavia, usam de dispositivos idênticos, desaparecido - ideia fixa - busca, que podem ser acrescidos ainda dos dados do passado conflituoso e futuro impossível, da perspectiva da morte e da circularidade, da memória e do esquecimento. Assim podemos ver uma fórmula de fazer romance, reforçada ao longo dessas obras, que são disparadas pelo desaparecido. Em suma, o desaparecido como dispositivo narrativo emula na estrutura narrativa os impasses do nosso fim de século: passado recalcado e futuro impossível. Benjamim, Eulálio e Francisco buscam "atar as duas pontas da vida", para usar uma metáfora de Bento Santiago ${ }^{37}$, tentando dar conta de uma totalidade atravessada pela matéria externa, e fracassam.

Podemos arriscar, ainda, ampliando o foco e refletindo sobre o espaço que os romances ocupam dentro de uma literatura brasileira contemporânea, alguns palpites. Primeiramente, uma consciência culposa de geração, índice dado pela repetição do desaparecido, com centralidade ou não. Referimo-nos aqui a uma geração de intelectuais que acompanha a desintegração do projeto de integração nacional (ou, pelo menos, parte dela), a sua reatualização na chave da modernização conservadora e que chega à redemocratização e ao final do século XX sob a égide do neoliberalismo e da falta de um projeto coletivo. Sem forçar a nota, pode-se dizer que essa promessa não foi levada a cabo nem com o lulismo, com uma integração que passou pelo consumo e não por um projeto de nação. Ao mesmo tempo, o próprio conceito de nação se tornou problemático, seja pelas discussões sobre o pluralismo de identidades, seja pelo uso da categoria como símbolo de defesa do país - em uma chave ligada a uma direita mais conservadora ou até mesmo saudosista do regime militar.

Uma segunda leitura, que não exclui a primeira, aponta para uma tentativa de recomposição de um passado perdido, dado externo do "país do futuro" que na

35 Idem. Leite derramado, op. cit.

36 GARCIA, Walter, op. cit.

37 ASSIS, Machado de. Dom Casmurro. Porto Alegre: L\&PM, 20I4. 
literatura tem se consolidado como uma produção atrelada ao passado, valendo-se da memória como artifício narrativo. A memória como categoria estruturante emerge na literatura recente quase como um recalque: os romances nos quais a ditadura se manifesta no conteúdo, mesmo que lateral, se passam em sua maioria, salvo engano, em um presente narrativo que rememora o passado ${ }^{38}$. Dito dessa maneira, pode-se pensar que mais importante que viver o período e suas narrativas é lembrá-lo como uma fantasmagoria, ao mesmo tempo que o futuro é apagado ou problematizado por esse espectro. Ou seja, é interrupção e presentismo puro, revelando um dado que é de estrutura: a prisão a um passado que teima em se repetir.

Se no enredo os desaparecidos são a ideia fixa, aumentando a lente e olhando em panorama, nos deparamos, dizendo de outra maneira, com o passado como ideia fixa, com a tentativa de reencontro como forma de nova elaboração ou, ainda, de expurgação de culpas, mas que sempre fracassa pela própria falta do dado externo de solução. Assim, a memória funciona como recriadora do passado, mas não se resolve no presente e, por consequência, acaba com o futuro. A morte à espreita deixa isso muito claro no dado ficcional: não há saída possível.

\section{CONSIDERAÇõES FINAIS}

Há uma importante tensão a se considerar aqui. De um lado, temos a não resolução do nosso passado recente e um esquecimento que paira sobre a sociedade com leis como a da Anistia, ou como a Comissão Nacional da Verdade - CNV 39 , instituída em 20I2, que, se é um trabalho a ser louvado, também há que se chamar a atenção para a sua composição tardia frente aos outros países latino-americanos. Engessada pelos acordos políticos de uma redemocratização “lenta e gradual”, a nossa CNV estava desde o início já sinalizada como uma comissão que não teria poder, por exemplo, para julgar nenhum crime. Por outro lado, temos uma classe artística que vem elaborando esteticamente essa experiência com cada vez mais frequência. Em tensão com o dado externo do esquecimento perpetuado desde I979, os romances, no melhor estilo freudiano ${ }^{40}$, recordam e repetem uma memória recalcada da e na sociedade. Dado que já havia sido apontado por Márcio Seligmann-Silva no cinema ${ }^{4 \mathrm{I}}$, funcionando assim a arte como o sonho: ou seja, como espaço de expurgação do inconsciente.

Pensando nas relações entre forma literária e processo histórico, retornamos a Roberto Schwarz, agora no seu texto "Fim de século":

\section{Ver nota 7.}

39 Instituída oficialmente em I2 de maio de 20I2. Para maiores informações ver: CNV - Comissão Nacional da Verdade. Disponível em: 〈http://www.cnv.gov.br/institucional-acesso-informacao/a-cnv.html〉. Acesso: 8 mar. 20I7.

40 FREUD, Sigmund. Recordar, repetir e elaborar (Novas recomendações sobre a técnica da psicanálise II). In: . O caso Schereber, artigos sobre técnica e outros trabalhos (I9II-I9I3). v.XII. Rio de Janeiro: Imago, I996.

4 I SELIGMANN-SILVA, M. Narrativas contra o silêncio: cinema e ditadura no Brasil In: SELIGMANN-SIVAL, M.; HARDMAN, F. F.; GINZBURG, J. Escritas da violência. v. II. Rio de Janeiro: 7 Letras, 2012. 
A pergunta não é retórica: o que é, o que significa uma cultura nacional que já não articule nenhum projeto coletivo de vida material, e que tenha passado a flutuar publicitariamente no mercado por sua vez, agora como casca vistosa, como um estilo de vida simpático a consumir entre outros? Essa estetização consumista das aspirações à comunidade nacional não deixa de ser um índice da nova situação também da... estética. Enfim, o capitalismo continua empilhando vitórias ${ }^{42}$.

Sem um projeto coletivo de integração nacional e à mercê do mercado, a pergunta do crítico ecoa. As aspirações de modernização que visavam a trazer uma massa da população para a cidadania fracassaram: do passado agrário ao presente urbano sem perspectivas. Ao mesmo tempo, os últimos anos trouxeram uma massa para o consumo e não propriamente para a cidadania. No plano estético, os narradores buarquianos se constroem na tensão do discurso que carrega em si o passado recalcado e a impossibilidade de futuro, entre esquecimentos e relativizações de culpas. Se o projeto de integração nacional foi interrompido pelo regime repressor, aquele, com a modernização conservadora e a violência real e simbólica do estado, surge como fantasmagoria desse passado não resolvido. Com a volta da democracia, aquele projeto não é retomado: não há horizontes de expectativa, o processo de modernização colapsou, para usarmos a expressão de Robert Kurz ${ }^{43}$, e quem manda é o mercado.

Diante da implacável força do mercado, um grande projeto de esquecimento vai ganhando forma. Neste ponto, cremos ser importante retomar, por fim, a entrevista de Suzana Lisboa, na qual afirma:

A tragédia se amplia no âmbito das famílias e permanece porque a sociedade brasileira vive esta violência hoje em função da impunidade dos crimes que foram cometidos. Não é apenas um Amarildo [ajudante de pedreiro Amarildo Dias de Souza, que desapareceu em 20I3 após ser detido por policiais militares na porta de sua casa, na Favela da Rocinha, Rio de Janeiro] que nós vivemos depois. São centenas de Amarildos, só que essas informações também são colocadas para debaixo dos panos. Quem ensinou a torturar, matar e desaparecer com os corpos? Foi a ditadura ${ }^{44}$.

Assim, a elaboração dos romances responde a um problema da realidade brasileira: uma sociedade estruturalmente violenta e que na nova dinâmica de mercado esperava na democracia um processo de inclusão de cidadania, mas sem um processo de acerto de contas com o passado. Essas fissuras retornam no presente como um problema político e estético que vem assombrar a sociedade e a literatura.

42 SCHWARZ, Roberto. Fim de século. In: . Sequências brasileiras. São Paulo: Companhia das Letras, I999, p. I62.

43 KURZ, Robert. O colapso da modernização: da derrocada do socialismo de caserna à crise da economia mundial. 6. ed. São Paulo: Paz e Terra, 2004.

44 LISBOA, Suzana apud NECCHI, Vitor, op. cit. 
JULIANE VARGAS WELTER é mestra e doutora em Literatura Brasileira pela Universidade Federal do Rio Grande do Sul (UFRGS) e professora adjunta do setor de Literatura Brasileira da Universidade Federal do Rio Grande do Norte (UFRN). E-mail: julianewelter@gmail.com

\section{REFERÊNCIAS BIBLIOGRÁFICAS}

ABREU, Caio F. Onde andará Dulce Veiga? Um romance b. Rio de Janeiro: Agir, 2007.

ASSIS, Machado. Memórias póstumas de Brás Cubas. São Paulo: Klick Editora, I997.

. Dom Casmurro. Porto Alegre: L\&PM, 20I4.

BRASIL. Presidência da República. Casa Civil. Subchefia para Assuntos Jurídicos. Lei n. 6.683, de 28 de agosto de I979. Concede anistia e dá outras providências. Disponível em: <http://www.planalto.gov. br/ccivil_03/leis/L6683.htm>. Acesso em: 3 mar. 2017.

BRUM, Eliane. Onde está Amarildo?. Época, 5 de agosto de 2013 (atualizado em I5 de agosto de 20I3). Disponível em: <http://epoca.globo.com/colunas-e-blogs/eliane-brum/noticia/20I3/o8/onde-estabamarildob.html >. Acesso em: 7 mar. 2017.

BUARQUE, Chico. Benjamim. São Paulo: Companhia das Letras, 2004.

. Leite derramado. São Paulo: Companhia das Letras, 2010.

. O irmão alemão. São Paulo: Companhia das Letras, 2014.

CAMPOS, Pedro Henrique Pedreira. Estranhas catedrais: as empreiteiras brasileiras e a ditadura civilmilitar. Niterói: Eduff, 20I4.

CNV - Comissão Nacional da Verdade. Disponível em: <http://www.cnv.gov.br/institucional-acesso-informacao/a-cnv/57-a-instalacao-da-comissao-nacional-da-verdade.html >. Acesso em: 8 mar. 2017.

FREUD, Sigmund. Recordar, repetir e elaborar (Novas recomendações sobre a técnica da psicanálise II). In:___ . O caso Schereber, artigos sobre técnica e outros trabalhos (I9II-I9I3). v. XII. Rio de Janeiro: Imago, I996.

GARCIA, Walter. De "A preta do acarajé" (Dorival Caymmi) a "Carioca” (Chico Buarque): canção popular e modernização capitalista no Brasil. Música Popular em Revista, Campinas, ano I, v. I, p. 30-57, jul.-dez. 20I2. Disponível em: <http://www.publionline.iar.unicamp.br/index.php/muspop/article/ view/28/46>. Acesso em: 8 abr. 2017.

KURZ, Robert. O colapso da modernização: da derrocada do socialismo de caserna à crise da economia mundial. 6. ed. São Paulo: Paz e Terra, 2004.

NECCHI, Vitor. Não há democracia onde houver desaparecidos. Entrevista especial com Suzana Lisboa. Instituto Humanitas Unisinos, $\mathrm{I}^{\mathrm{o}}$ de março de 20I7. Disponível em: <http://www.ihu.unisinos.br/ maisnoticias/noticias?id=565160:nao-ha-democracia-onde-houver-desaparecidos-entrevista-especialcom-suzana-lisboa >. Acesso em: 3 mar. 2017.

PASTA JÚNIOR, José Antonio. O ponto de vista da morte. Revista da Cinemateca Brasileira, v. I, p. 7-I5, 20I3. RICOEUR, Paul. A memória, a história, o esquecimento. Campinas: Editora da Unicamp, 2007. 
SCHWARZ, Roberto. Fim de século. In: . Sequências brasileiras. São Paulo: Companhia das Letras, I999. . Um romance de Chico Buarque. In: . Sequências brasileiras. São Paulo: Companhia das Letras, I999.

. Cetim laranja sobre fundo escuro. In: . Martinha versus Lucrécia. São Paulo: Companhia das Letras, 2012.

SELIGMANN-SILVA, M. Narrativas contra o silêncio: cinema e ditadura no Brasil. In: SELIGMANN-SIVAL, M.; HARDMAN, F. F.; GINZBURG, J. Escritas da violência. v. II. Rio de Janeiro: 7 Letras, 2012.

SILVA, Fernando Barros e. O irmão brasileiro. Piauí, edição Ioo, janeiro de 20I5. Disponível em: <http:// piaui.folha.uol.com.br/materia/o-irmao-brasileiro >. Acesso em: 4 mar. 2017.

WELTER, Juliane Vargas. Em busca do passado esquecido: uma análise dos romances Onde andará Dulce Veiga? (I990), de Caio Fernando Abreu, e Benjamim (I995), de Chico Buarque. 20I5. 267 f. Tese (Doutorado em Estudos Literários). Programa de Pós-Graduação em Letras, Instituto de Letras, Universidade Federal do Rio Grande do Sul, 20I5. Disponível em: 〈http://www.lume.ufrgs.br/handle/IoI83/II7544〉. Acesso em: 4 mar. 2015.

E se estou vendo fantasmas?. Resenha do romance Cabo de guerra, de Ivone Bendetti). Blog da Boitempo, 29 de julho de 20I6. Disponível em: <https://blogdaboitempo.com.br/20I6/o7/29/e-se-estou-vendo-fantasmas $>$. Acesso em: 3 mar. 2017. 